\title{
Workshop Perakitan Komputer Untuk Guru MI Mathla'ul Huda Cijantra
}

\author{
Eriyandi $^{1}$, Johan Wahyudi ${ }^{2}$, Sabdo Purnomo ${ }^{3}$, Toni ${ }^{4}$, Suparlan $^{5}$ \\ 1,2,3,4,5,6 Politeknik Penerbangan Indonesia Curug \\ e-mail: ${ }^{1}$ eriyandi@ @picurug.ac.id, ${ }^{2}$ johan.wahyudi@ ppicurug.ac.id, ${ }^{3}$ sabdo.purnomo@ppicurug.ac.id, \\ ${ }^{4}$ toni@ppicurug.ac.id, ${ }^{5}$ suparlan@ppicurug.ac.id
}

\begin{abstract}
Abstrak
Perkembangan ilmu pengetahuan pada saat ini hampir tidak bisa terlepas dari teknologi khususnya teknologi informasi, karenanya sumber daya manusia yang berkecimpung dalam bidang apapapun dituntut untuk mampu beradaptasi dengan kemajuan teknologi yang ada. Dalam dunia pendidikan, pemerintah sudah banyak melakukan kegiatan untuk meningkatkan kompetensi para pengajar, salah satunya dengan memberikan pelatihan-pelatihan penggunaan perangkat teknologi informasi di bidang pendidikan dan pengajaran, yang nantinya akan di terapkan di sekolah-sekolah dan lembaga Pendidikan lainnya. Namun demikian berdasarkan realita yang ada di sekitar PPI Curug, masih banyak sekolah-sekolah yang sarana dan prasarana teknologinya belum memadai, salah satunya di MI Mathla'ul Huda yang ada di Cijantra Jl. Gunung Batu Desa Cijantra Kecamatan Pagedangan, dimana sebagian muridnya adalah anak yatim/piatu dan kurang mampu. Permasalahan muncul ketika terjadi gangguan pada perangkat komputer yang digunakan sementara pengetahuan guru-guru di masih minim. Untuk mengatasi permasalahan tersebut fihak MI terpaksa harus mengeluarkan biaya ekstra untuk perbaikan dan pemulihan yang tentunya hal ini menjadi beban bagi fihak sekolah. Karenanya melalui kegiatan pengabdian kepada masyarakat kali ini ditujukan untuk memberikan pendidikan dan pelatihan kepada guru-guru tentang cara merakit dan menginstal perangkat komputer. Setelah mengikuti pendidikan dan pelatihan melalui workshop yang diadakan Politeknik Penerbangan Indonesia Curug, maka guru-guru sudah memiliki pengetahuan dan keterampilan untuk menginstal dan merakit komputer, sehingga ketika terjadi gangguan pada perangkat komputer sudah bisa diatasi sendiri, dan guru-guru yang mayoritas sebagai tenaga honorer bisa memperoleh tambahan pendapatan bermodalkan pengetahuan yang mereka dapat selama mengikuti workshop.
\end{abstract}

Kata Kunci : Komputer, Merakit, Workshop.

The development of science at this time can hardly be separated from technology, especially information technology, therefore human resources who are involved in any field are required to be able to adapt to existing technological advances. In the world of education, the government has carried out many activities to improve the competence of teachers, one of which is by providing trainings on the use of information technology tools in education and teaching, which will later be applied in schools and other educational institutions. However, based on the reality around PPI Curug, there are still many schools with inadequate technological facilities and infrastructure, one of which is MI Mathla'ul Huda which is on Cijantra Jl. Gunung Batu Cijantra Village, Pagedangan Subdistrict, where some of the students are orphans and underprivileged. The problem arises when there is problem with the computer equipment used while the teachers' knowledge is still minimal. To overcome this problem MI was forced to pay extra for repairs and restoration, which of course became a burden for the school. Therefore, through community service activities this time it is aimed at providing education and training to teachers on how to assemble and install computer equipment. After attending education and training through workshops held by the Indonesian Aviation Polytechnic of Curug, the teachers already have the knowledge and skills to install and assemble computers so that when a problem occurs on a computer devices, it can be resolved by themselves, and teachers who are mostly honorary staff can get additional income with the knowledge they get during the workshop.

Keywords : Computer, Instalation, Workshop.. 


\section{Pendahuluan}

Perkembangan ilmu pengetahuan pada saat ini hampir tidak bisa terlepas dari teknologi khususnya teknologi informasi/komputer, karenanya sumber daya manusia yang berkecimpung dalam bidang apapapun dituntut untuk mampu beradaptasi dengan kemajuan teknologi yang ada. Pemerintah akhir-akhir ini sudah menggalakkan kegiatan-kegiatan untuk meningkatkan kompetensi para pengajar yang ada di lingkungan sekolah, salah satunya dalam bentuk pelatihan ataupun workshop. Akan tetapi sayangnya kegiatan tersebut masih jarang sekali dilaksanakan sehingga para pengajarnya masih memiliki pengetahuan yang minim karena kurangnya kegiatan-kegiatan untuk meningkatkan kompetensi diri guru. Hal ini akan menjadi kendala ketika sekolah dihadapkan dengan persoalan yang berkaitan dengan teknologi komputer, karena tidak memiliki keahlian maka mau tidak mau sekolah harus mengeluarkan biaya ekstra untuk membayar jasa perbaikan dan perawatan juga penginstalan perangkat baru komputer.

Berdasarkan beberapa ulasan sebelumnya, timbul sebuah pertanyaan, bagaimana dengan sekolah yang sumber pendanaannya sangat minim serta sarana dan prasarana yang kurang memadai. Salah satu sekolah yang dimaksud adalah MI Mathla'ul Huda yang berlokasi di Cijantra Jl. Gunung Batu Desa Cijantra Kecamatan Pagedangan. Sekolah ini adalah sekolah Swasta dibawah naungan Kemenag dengan SK Pendirian sekolah : D/MI-04/mi/050/1998 dengan SK ijin operasional No. Di MI Mathla'ul Huda ini sebagian besar muridnya adalah anak yatim/piatu dan kurang mampu, tetapi mereka tetap diberikan kesempatan untuk sekolah seperti anak anak yang lain tanpa dipungut biaya. Walaupun dengan kondisi minim sumber pendanaan tetapi sekolah tetap berupaya untuk membantu mencerdaskan kehidupan anak anak bangsa dan guru-gurunya yang dituntut untuk terus meningkatkan kualitas pengetahuan dan kompetensi sementara disisi lain sekolah tidak mempunyai biaya untuk hal tersebut. Karenanya Politeknik Penerbangan Indonesia Curug dalam rangka mewujudkan salah satu Tri Dharma Perguruan Tinggi yaitu Pengabdian Kepada Masyarakat, maka diadakanlah pelatihan dalam bentuk workshop tentang perakitan komputer di MI Mathla'ul Huda, Setelah selesai mengikuti kegiatan ini para guru sudah memiliki bekal ilmu dan mampu melaksanakan perawatan dan perakitan komputer, hal ini bisa terlihat dalam waktu dua hari para guru sudah dapat merakit komputer dan memperbaikinya jika terjadi masalah pada hardware dan softwarenya. Manfaat lain yang juga diperoleh dari workshop ini adalah para guru yang Sebagian besar masih tenaga honorer berpeluang memperoleh tambahan penghasilan berbekal ilmu perakitan komputer yang diperoleh dari Tim Politeknik Penerbangan Indonesia Curug.

\section{Metode}

Metode yang digunakan dalam kegiatan pengabdian kepada masyarakat ini adalah program pelatihan berbentuk On the Job Training, dimana para peserta akan dilatih langsung untuk mengerjakan suatu kegiatan dan meniru suatu pekerjaan dibawah bimbingan dari Tim Politeknik Penerbangan Indonesia Curug. Kegiatan dilaksanakan di dua tempat selama dua hari, yaitu hari pertama dilaksanakan di PPI Curug untuk pelatihan dan praktek perakitan komputer dan hari kedua dilaksanakan di MI Mathla'ul Huda untuk lanjutan praktek perakitan komputer dan install software dan setelah ishoma dilanjutkan dengan ujian prakter untuk evaluasi hasil pelatihan. Peserta pelatihan adalah para guru disekolah tersebut. Adapun jadwal pelaksanaan kegiatan dapat dilihat pada Tabel 1. 
Tabel 1. Jadwal Pelatihan Perakitan Komputer

\begin{tabular}{|c|c|l|}
\hline NO & WAKTU & \multicolumn{1}{|c|}{ KEGIATAN } \\
\hline \multicolumn{1}{|c|}{ Hari Pertama : 14 Desember 2020 di PPI Curug } \\
\hline 1 & $08.00-08.15$ & Persiapan di Gedung CNS \\
\hline 2 & $08.15-08.30$ & Peserta Kumpul di Unit Kesehatan \\
\hline 3 & $08.30-09.00$ & Rapid Test seluruh peserta PKM \\
\hline 4 & $09.00-09.30$ & Foto bersama dan Pembukaan PKM \\
\hline 5 & $09.00-12.00$ & $\begin{array}{l}\text { Pemberian Materi tentang Perakitan Komputer olehDosen/Pengajar } \\
\text { dari PPI Curug }\end{array}$ \\
\hline 6 & $12.00-13.00$ & ISHOMA \\
\hline 7 & $13.00-16.00$ & $\begin{array}{l}\text { Kegiatan Praktek Perakitan Komputer oleh Dosen/Pengajar dari PPI } \\
\text { Curug }\end{array}$ \\
\hline Hari Kedua : 15 Desember 2020 di MI Mathla'ul Huda Cijantra \\
\hline 1 & $08.00-11.30$ & $\begin{array}{l}\text { Lanjutan Praktek Perakitan Komputer oleh Dosen/Pengajar dari PPI } \\
\text { Curug Praktek instalasi perangkat lunak }\end{array}$ \\
\hline 2 & $11.30-13.00$ & ISHOMA \\
\hline 3 & $13.00-16.00$ & Ujian Praktek Upgrade komputer di MI Mathla'ul Huda \\
\hline 4 & $16.00-16.30$ & Penutupan PKM Prodi TNU \\
\hline
\end{tabular}

\section{Hasil dan Pembahasan}

Hasil dari kegiatan pengabdian kepada masyarakat dalam bentuk pelatihan terhadap guru-guru di MI Mathla'ul Huda selama dua hari, hari pertama para guru diberi pemahaman tentang cara menentukan konfigurasi komputer yang berkaitan dengan penentuan jenis komponen dan fitur komputer yang dapat bekerjasama sebagai sebuah sistem komputer sesuai yang diinginkan. Selain itu para guru juga diajarkan untuk memahami faktor kesesuaian dan kompatibilitas dari komponen terhadap motherboard.

Setelah diberi bekal pemahaman tentang konfigurasi komputer, para guru diminta mempersiapkan komponen dan perlengkapan untuk merakit komputer. Setelah itu Tim PPI Curug memberikan arahan kepada guru tentang tata cara perakitan komponen yang baik dan benar. Modul manual diberikan kepada peserta untuk mengetahui diagram posisi dari elemen koneksi dan elemen konfigurasi beserta cara setting jumper dan switch yang sesuai untuk computer yang dirakit. CD software juga disiapkan untuk menginstall sistem operasi setelah komputer selesai dirakit.

Hari kedua kegiatan dilanjutkan dengan praktek menginstall komputer bagi semua peserta secara berkelompok dibawah arahan dan bimbingan Tim PPI Curug. Peserta sangat antusias ingin belajar dan banyak pertanyaan yang dilontarkan saat proses perakitan berjalan. Setelah selesai merakit komputer dilanjutkan dengan menginstall sistem operasi komputer. Setelah semua langkah perakitan dan penginstallan selesai maka komputer dioperasikan dan berhasil beroperasi dengan baik. Proses pelaksanaan kegiatan pelatihan selengkapnya di dokumentasikan dalam bentuk foto-foto kegiatan yang dapat dilihat pada Gambar 1 dan Gambar 2. Sebagai bentuk perhatian dan support Tim PPI Curug kepada MI Mathla'ul Huda, setelah para guru berhasil merakit perangkat komputer dengan benar, maka hasil rakitan mereka berupa satu unit komputer rakitan dan monitor langsung diserahkan ke fihak sekolah supaya dapat dimanfaatkan untuk memperlancar kegiatan pembelajaran siswanya. 

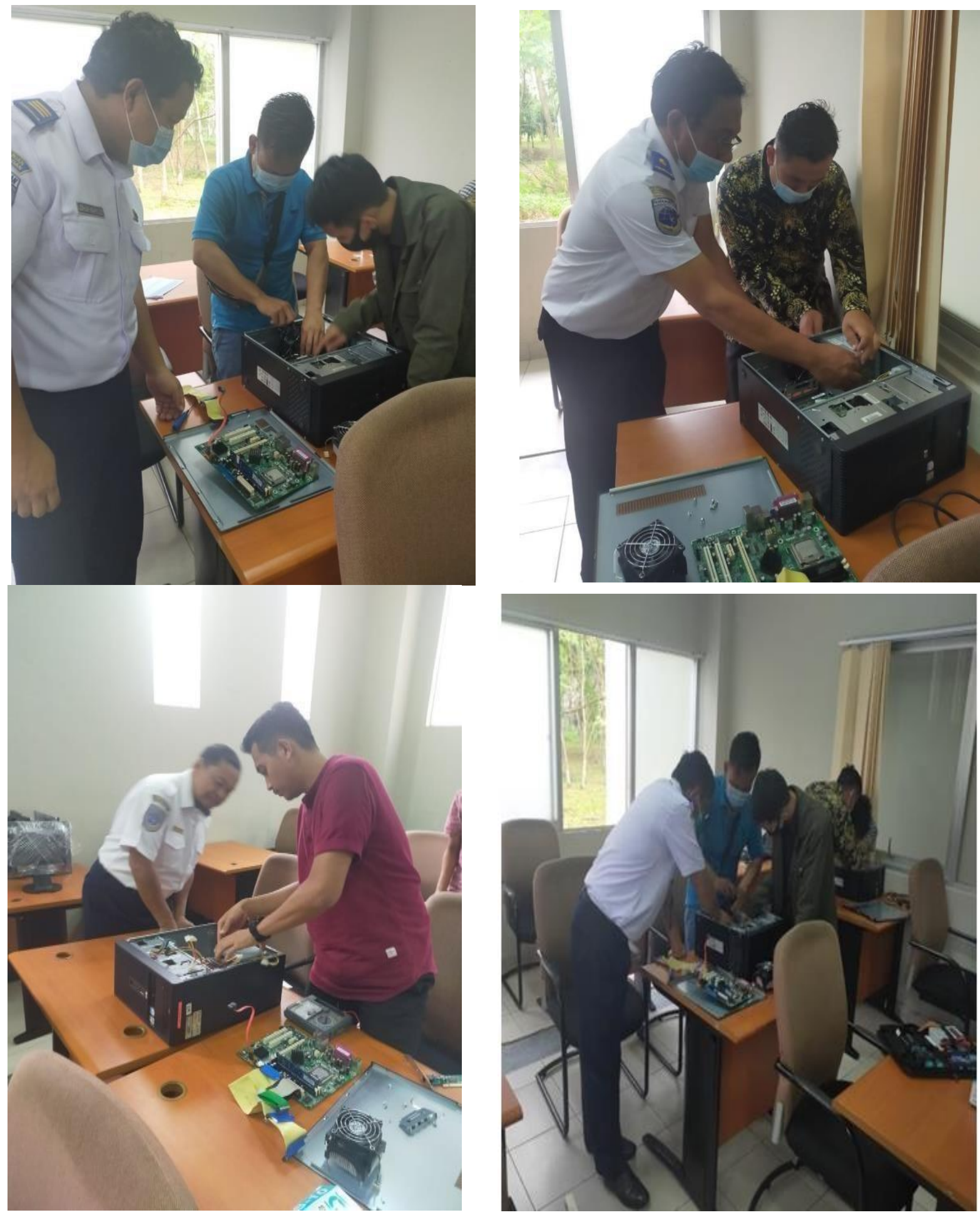

Gambar 1. Foto - foto kegiatan pelatihan hari pertama 

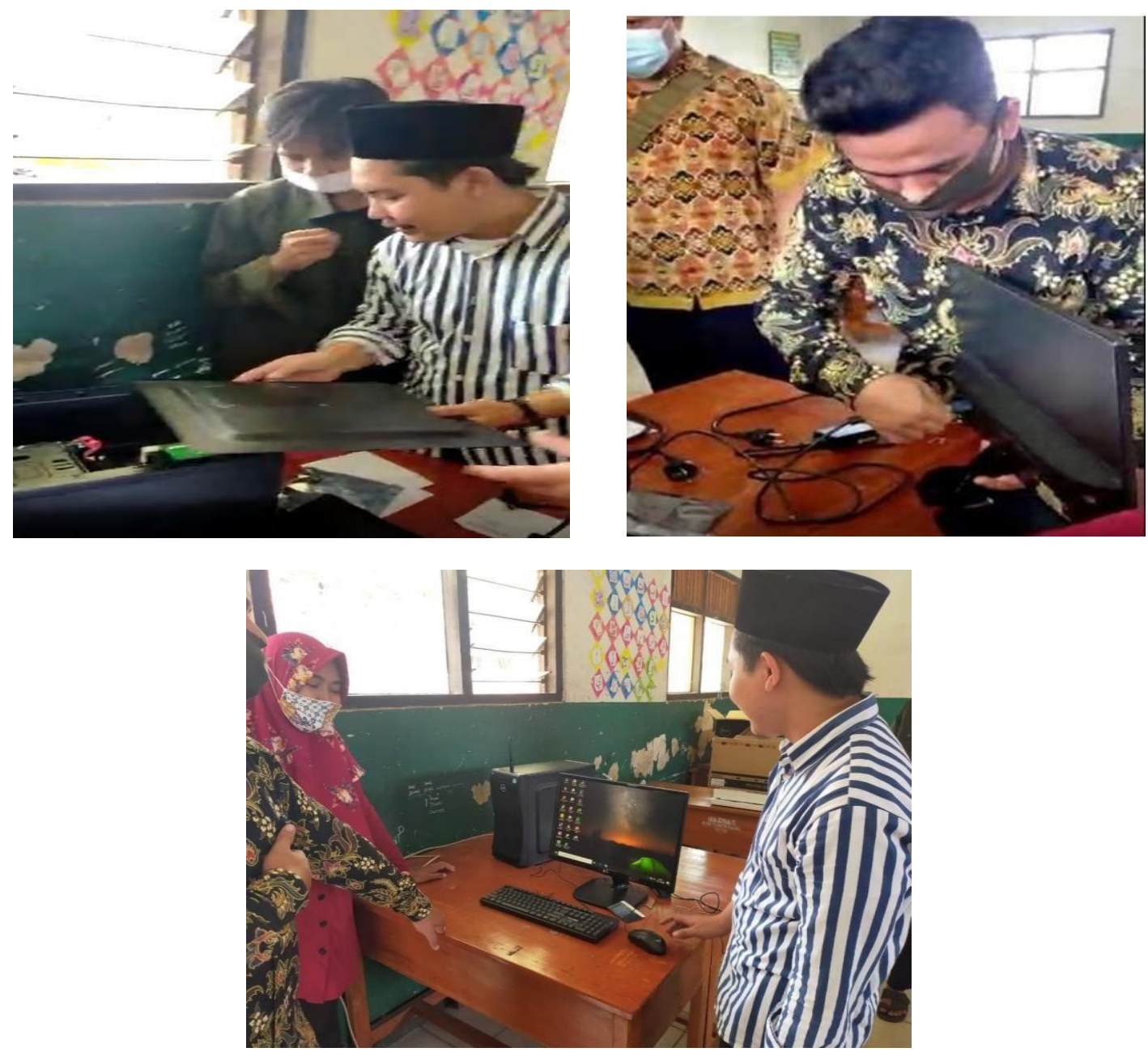

Gambar 2. Foto - foto kegiatan pelatihan hari kedua

\section{Kesimpulan}

Dari hasil evaluasi yang kami peroleh selama pelaksanaan pelatihan dalam bentuk workshop dapat kami simpulkan bahwa bahwa kegiatan pengabdian kepada masyarakat sebagai perwujudan salah satu Tri Dharma perguruan Tinggi dapat memberikan manfaat langsung bagi guru-guru di MI Mathla'ul Huda. Bentuk pelatihan inilah yang paling efektif untuk menambah pengetahuan dan keterampilan baru di bidang teknologi informasi, karena setelah selesai mengikuti pelatihan dan saat dilakukan ujian praktek di hari kedua, para guru sudah berhasil dan terampil merakit komponen komputer dari komponen part menjadi unit komputer yang siap pakai.

Selain itu PPI Curug juga telah membantu membuka peluang usaha baru bagi para guru dalam upaya menambah penghasilan, karena mereka sudah bisa menjual jasa perakitan maupun perbaikan unit komputer bagi fihak-fihak yang membutuhkan.

\section{Penghargaan/Ucapan terima kasih}

Penulis mengucapkan terima kasih kepada Anggaran DIPA Politeknik Penerbangan Indonesia Curug Tahun Anggaran 2020, yang telah memberikan dana sehingga penulis dapat melaksanakan kegiatan Pengabdian Kepada Masyarakat. 


\section{Daftar Pustaka}

Bakrum, M (2019), "Paparan Direktur Pembinaan SMK (PSMK) Kemendikbud Republik Indonesia"

Budi, P. (2007), “Merakit Komputer Dengan Cepat Secara Otodidak”, Komunitas eLearning Ilmu Komputer.com, Copyright $@$ 2003-2007 Ilmu Komputer.com

Heru, "Cara Merakit Komputer Beserta Gambarnya Lengkap", http://heru1745.multiply.com

Modul Pemula Merakit PC, https://dokumen.tips/documents/modul-pemula-merakitkomputerpdf.html

Nurdiansyah, M.F. dan Hamdani, MS, "Merakit PC"

Napisah (2004), "Modul Pembelajaran Berbasis Multimedia Merakit Personal Computer (PC)", Fakultas Sains dan Teknologi Universitas Islam Negeri Syarif Hidayatullah, Jakarta Undang Undang No. 20 Tahun 2003 tentang Sistem Pendidikan Nasional 